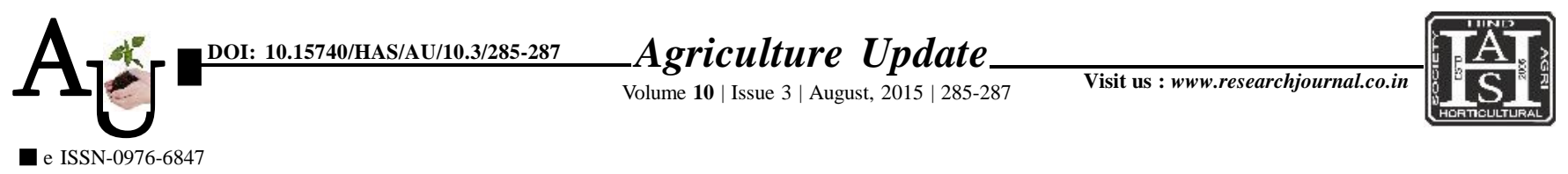

\title{
Research Note: Development of scale to measure attitude of the beneficiaries towards Mahatma Gandhi National Rural Employment Guarantee Act Programme
}

\author{
GORDHAN SINGH BHATI, SUNIL R. PATEL AND KESHA RAM
}

Article Chronicle : Received :

03.08.2015;

Accepted :

30.08.2015

KeY Words :

Beneficiaries attitude
SUMMARY : The MNREGA is a right based scheme implemented by the government aiming to enhance livelihood security of rural people. It is a holistic programme encompassing employment opportunities, women empowerment and creation of durable assets for the community. It has mainly been enacted for checking distress migration of rural youth for search of job in city area during off season. Thus, the scheme is vital for uplifting poor people and rural youth through provision of employment. Hence, it becomes essential that it is properly availed. Here an effort was made to develop a scale which can measure attitude of beneficiaries towards MNREGA. Among the techniques available, 'scale product method' was chosen to develop the scale. The scale developed was found highly reliable as the coefficient of reliability calculated by the Rulon's formula was 0.79 .

How to cite this article : Bhati, Gordhan Singh, Patel, Sunil R. and Ram, Kesha (2015). Development of scale to measure attitude of the beneficiaries towards Mahatma Gandhi National Rural Employment Guarantee Act Programme. Agric. Update, 10(3): 285-287.
Author for correspondence :

\section{GORDHAN SINGH}

\section{BHATI}

Department of Extension Education, B.A. College of Agriculture, Anand Agricultural University, ANAND (GUJARAT) INDIA Email: gsbhati89@gmail. com

See end of the article for authors' affiliations 